ISSN: 1907-9931 (print), 2476-9991 (online)

\title{
IDENTIFIKASI IKAN SARDIN KOMERSIAL (Dussumieria elopsoides) YANG DIDARATKAN DI PASAR MUARA ANGKE, JAKARTA MENGGUNAKAN PENGAMATAN MORFOLOGI, MORFOMETRIK DAN DNA BARCODING IDENTIFICATION OF COMMERCIAL SARDIN FISH (Dussumieria elopsoides) IN MUARA ANGKE MARKET, JAKARTA USING MORPHOLOGY, MORPHOMETRIC AND DNA BARCODING OBSERVATIONS
}

\author{
Zakiyah Rahim*, Hawis Madduppa \\ Departemen IImu dan Teknologi Kelautan, FPIK IPB, Bogor, 16680, Indonesia \\ *Corresponden author e-mail: 040496zakiyahrahim@ipb.ac.id
}

Submitted: 09 January 2020 / Revised: 09 July 2020 / Accepted: 09 July 2020

http://doi.org/ 10.21107/jk.v13i2.6397

\begin{abstract}
Sardines are an important commodity in import activities. Excessive imports and lack of catch data are feared to reduce fish stocks. To complete the fish catch data required knowledge of body type and size. This study aims to identify and confirm commercial sardines species landed at Muara Angke Market, Jakarta using morphological, morphometric, and DNA barcoding methods targeting the Mitochondrial Cytochrome c oxidase-I (COI) gene. The results of morphological and morphometric analysis showed that the samples are the genus Dussumieria originating from the Dussumieriidae family, the Order Clupeidae, having silver-colored body characteristics with reflections resembling rainbows, slender bodies and rounded stomachs with a maximum length of up to $14.4 \mathrm{~cm}$, then less abdominal fins advance from the midsection. Based on the relationship of body weight length, this fish is negative allometric. Molecular DNA barcoding analysis using COI, obtained by type of Dussumieria elopsoides fish with local name of rainbow sardines, similarity level with Query Cover percentage was $94 \%$ and Per percentage. Ident of 91.64\%. DNA barcoding analysis has corroborated morphological and morphometric observations by obtaining fish samples identified as Dussumieria elopsoides.
\end{abstract}

Keywords: Morphology, Morphometrics, DNA Barcoding, Dussumiera elopsoides.

\section{ABSTRAK}

Ikan sardin merupakan komoditas penting dalam kegiatan impor. Impor berlebih serta kurangnya data penangkapan dikhawatirkan dapat menurunkan stok ikan. Untuk melengkapi data tangkapan ikan diperlukan pengetahuan mengenai jenis dan ukuran tubuhnya. Penelitian ini bertujuan untuk mengidentifikasi dan memastikan jenis ikan sardin komersial yang didaratkan di Pasar Muara Angke, Jakarta dengan menggunakan studi morfologi, morfometrik, dan metode DNA barcoding dengan target gen Mitokondrial Cytochrome c oxidase-I (COI). Hasil analisa morfologi dan morfometrik menunjukkan bahwa sampel merupakan genus Dussumieria berasal dari famili Dussumieriidae, Ordo Clupeidae, memiliki karakteristik tubuh yang berwarna silver dengan pantulan menyerupai pelangi, tubuh ramping dan perut membulat dengan panjang maksimal dapat mencapai 14,4 cm, kemudian sirip bagian perut kurang maju dari bagian tengah tubuhnya. Berdasarkan hubungan panjang berat badan, ikan ini bersifat alometrik negatif. Analisis DNA barcoding secara molekuler menggunakan COI, didapatkan ikan berjenis Dussumieria elopsoides dengan nama lokal ikan sardin pelangi, tingkat kemiripan dengan presentase Query Cover sebesar 94\% dan presentase Per. Ident sebesar 91,64\%. Analisis DNA Barcoding telah menguatkan pengamatan morfologi dan morfometrik dengan didapatkan sampel ikan yang teridentifikasi berjenis Dussumieria elopsoides.

Kata Kunci: Morfologi, Morfometrik, DNA Barcoding, Dussumiera elopsoides. 


\section{PENDAHULUAN}

Ikan Sardin merupakan salah satu komoditas perikanan yang banyak diminati oleh masyarakat secara global khususnya di Indonesia. Terbukti dengan meningkatnya tingkat konsumsi ikan di Indonesia dari tahun ke tahun, hingga meningkatnya jumlah ekspor ikan sardin ke negara tetangga. Perkembangan impor ikan sardin mengalami peningkatan sebanyak $137,49 \%$ pada periode 2016-2017 (Sekjen KKP RI, 2018). Tingginya minat beli masyarakat terhadap ikan ini, menjadikan ikan ini sebagai komoditas ikan yang penting dalam meningkatkan perekonomian Indonesia. Namun penangkapan ikan yang berlebihan dan tidak terkendali dapat menurunkan nilai stok perikanan, contohnya terjadi pada negara India, dimana pada tahun 1943 daerah Madras di India mengalami penurunan dan jatuhnya stok ikan sardin akibat overfishing (Kripa et al., 2018).ekplorasi sumberdaya yang terus meningkat, makadiperlukan usaha untuk mengetahui dan mengevaluasi terjadinya penururnan stok dan kepunahan dari suatu spesies.

Penelitian biologi perikanan sangat penting dilakukan untuk pendugaan dari probabilitas suatu spesies di perairan. Salah satu ilmu pada bidang biologi perikanan yang dapat dimanfaatkan dalam pendugaan dan pendataan suatu spesies di perairan yaitu dengan menggunakan studi morfologi, morfometrik dan metode DNA barcoding yang telah dilakukan pada ikan Dussumieria elopsoides (Keskin dan Atar, 2013). Penggunaan data morfometrik dinilai penting untuk menentukan apakah ikan yang tertangkap sudah layak untuk diambil, sedangkan penggunaan DNA barcoding dilakukan untuk memverifikasi apakah ada kesalahan atau tidak dalam penentuan taksonomi ikan yang diteliti, karena selama ini beberapa spesies ikan mengalami ambiguitas dalam taksonomi (Ko et al., 2013). Contoh kesalahan yang terjadi dalam identifikasi secara morfologi yaitu pada penelitian Abdullah dan Rehbein (2016), dimana terdapat 6 spesies ikan pari teridentifikasi sebagai Eusphyra blochii, namun setelah diidentifikasi menggunakan genetika molekuler spesies tersebut merupakan Sphyrna lewisi. Genetika molekuler dibutuhkan terkait dengan ketepatan mengidentifikasi spesies dan mendukung hasil identifikasi berdasarkan sifat morfologi. Identifikasi secara akurat pada suatu organisme dari tingkat genus hingga subspesies secara morfologi sulit dibedakan dan menimbulkan ambiguitas, sehingga dapat menggunakan DNA barcoding (Hebert et al., 2003). Ambiguitas dan kesalahan dalam identifikasi suatu spesies dapat menjadi ancaman bagi kegiatan konservasi maupun perikanan berkelanjutan (Sembiring et al., 2015). Beberapa penelitian telah mampu mengidentifikasi ikan komersil dari perairan Indonesia menggunakan teknik genetika molekuler diantaranya pada ikan kakap (Lutjanus), kerapu (Epinephelus), makarel (Scomberomorus), tuna (Thunnus) (Abdullah dan Rehbein 2016; Jefri et al., 2015; Maulid et al., 2016 Nurimala et al., 2016 : Akbar dan Labenua, 2018). Manfaat studi morfometrik sendiri yaitu dapat mengetahui dan mendeskripsikan pola pola keragaman morfologis dan pola pertumbuhan baik itu antar populasi ataupun spesies (Strauss \& Bond, 1990).

Penerapan metode yang sesuai untuk identifikasi ikan yang akurat dan cepat, sangat penting untuk membantu dalam mengelola perikanan keberlanjutan dalam jangka panjang dan diharapkan mampu meningkatkan ketersedian di ekosistemnya, serta mampu meningkatkan nilai konservasi. Tujuan dari penelitian ini yaitu untuk mengetahui spesies ikan sardin yang tertangkap berdasarkan pengamatan morfologi pengukuran morfometrik dan memverifikasi jenis spesies sampel menggunakan DNA barcoding, serta untuk mengetahui hubungan panjang dan berat tubuhnya. Dengan adanya penelitian ini, diharapkan mampu membantu pemerintah dalam mendapatkan informasi mengenai perikanan tangkap maupun upaya dalam konservasi sumber daya perikanan laut, terutama pada bidang genetika molekuler.

\section{MATERI DAN METODE Lokasi Pengambilan Sampel}

Sampel diambil di Pasar Muara Angke Jakarta Utara pada bulan Oktober 2019. Pengukuran dilakukan di lapangan sedangkan analisis morfometrikk dan analisisi molekuler dilakukan di Laboratorium Biosistematik dan Genetika Kelautan, Departemen IImu Kelautan, Fakultas Perikanan dan IImu Kelautan, Institusi Pertanian Bogor.

\section{Pengamatan Morfologi dan Morfometrik}

Sebanyak 30 ekor sampel dikumpulkan menggunakan metode sampling acak. Sampel diambil dari tengkulak ikan yang terdapat di Pasar Muara Angke. 30 individu kemudian 
Rahim dan Maduppa, Identifikasi Ikan Sardin Komersial (Dussumieria elopsoides)

diamati morfologinya. 22 karakter morfometrikk diukur pada tiap 30 ekor sampel (Myers, 2013). Karakter morfometrikk sampel yang diukur yaitu 1. Panjang Total (PT), 2. Panjang Standar (PS), 3. Panjang Kepala (PK), 4. Panjang Sebelum Sirip Dorsal (PSSD), 5. Panjang Sebelum Sirip Ventral (PSSV), 6. Panjang Sebelum Sirip Anus (PSSA), 7. Tinggi Kepala (TK), 8. Tinggi Badan (TB), 9. Tinggi Pangkal Ekor (TPE), 10. Panjang Batang Ekor (PBE), 11. Panjang Dasar Sirip Dorsal (PDSD), 12. Panjang Dasar Sirip Anus (PDSA), 13. Panjang Dasar Sirip Ventral (PDSV), 14. Panjang Dasar Sirip Pektoral (PDSP), 15. Panjang Sirip Ekor
Bagian Atas (PSEA), 16. Panjang Sirip Ekor Bagian Tengah (PSET), 17. Panjang Sirip Ekor Bagian Bawah (PSEB), 18. Panjang Moncong (PM), 19. Diameter Mata (DM), 20. Jarak Mata ke Tutup Insang (JMTI), 21. Jarak Antar Mata (JAM), 22. Lebar Badan (LB). Perhitungan Morfometrik ditampilkan pada Gambar 1. Setiap sampel yang telah diukur morfometriknya menggunakan jangaka sorong kemudian ditimbang lalu difoto untuk kemudian didigitasi menggunakan CorelDraw. Salah satu sampel ikan diambil bagian ekornya lalu dipreservasi menggunakan etanol $96 \%$ untuk digunakan dalam anaisis molekuler (DNA barcoding).

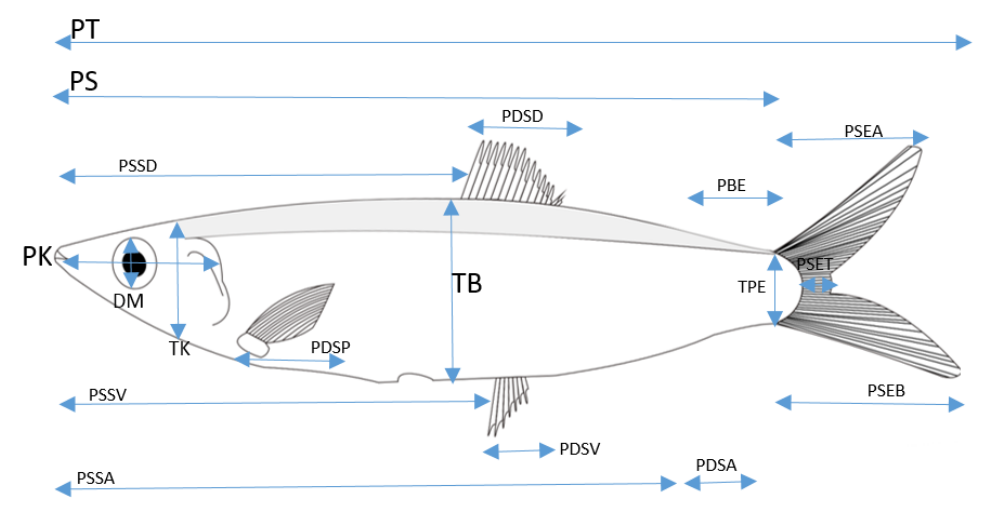

\section{Molekuler}

Gambar 1. Pengukuran Morfometrik (Myers, 2013)

Tahapan yang dilakukan dalam analisis molekuler yaitu meliputi ekstraksi DNA, amplifikasi DNA menggunakan Polymerase Chain Reaction (PCR), visualisasi fragmen DNA menggunakan elektroforesis, dan sequensing DNA. Jaringan ekor ikan yang telah dipreservasi kemudian dijadikan sebagai bahan ekstraksi DNA. Ekstraksi DNA $25 \mathrm{mg}$ sampel ikan mengunakan gSYNC DNA Extraction Kit (Geneaid, Taiwan) dan mengikuti prosedur manualnya. Hasil ekstraksi kemudian digunakan dalam proses amplifikasi. Amplifikasi DNA dengan menggunakan PCR pada Mitochondrial Cytochrome C Oxidase Subunit I (COI). Komponen yang digunakan dalam proses PCR yiatu DNA template $1 \mu \mathrm{l}$, Primer 1,25 $\mu \mathrm{l}$, DDH2O $9 \mu$, dan MyTaq 12,5 $\mu$ l. Primer yang digunakan yaitu FishF1 (5'TCAACCAACCACAAAGACATTGGCAC-3') dan FishR1 TAGACTTCTGGGTGGCCAAAGAAT CA-3' (Ward et al., 2005). Proses PCR mengikuti manual Geneaid dan menggunakan alat DIAB Mastercycler DNA Engine Thermal Cycle. PCR dilakukan dengan proses denaturasi awal dengan suhu $94^{\circ} \mathrm{C}$ selama 30 detik, diikuti dengan 38 siklus amplifikasi (denaturasi pada suhu $94{ }^{\circ} \mathrm{C}$ selama 30 detik, anneling pada suhu $50{ }^{\circ} \mathrm{C}$ selama 1 menit, dan elongasi pada $72{ }^{\circ} \mathrm{C}$ selama 1 menit) dan elongasi akhir pada $72{ }^{\circ} \mathrm{C}$ selama 7 menit, kemudian diikuti pendinginan pada suhu $4{ }^{\circ} \mathrm{C}$ selama 5 menit. Hasil dari proses PCR kemudian divisualisasi mengguakan elektroforesis dalam $1 \%$ gel agarose. Hasil visualisasi DNA yang terlihat jelas dalam UV transilluminator, diyakini memiliki kualitas yang baik dan dapat dilanjutkan ke tahap sequensing DNA. Hasil amplifikasi kemudian dikirim dan dianalisis ke The 1st BASE $\AA$ service di Singapore untuk mengetahui urutan basa nukleotida dari DNA tersebut.

\section{Analisis Data}

Identifikasi berdasarkan morfologi dan morfometrik dianalisa dengan menggunakan buku identifikasi FAO Species Catalog Vol. 7 Clupeoid Fishes Of The World (Whitehead, 1985). Analisis hubugan panjang dan berat tubuh menggunakan metode Santos et al. (2002) yaitu dengan menggunakan persamaan Linear Allomatric Model.

$\mathrm{W}=\left(\mathrm{aL}^{\mathrm{b}}\right)$

$\mathrm{W}=$ berat ikan (gram) 
Jurnal Kelautan, 13(2), 93-99 (2020)

$\mathrm{L}=$ panjang ikan $(\mathrm{cm})$

$a=$ intercept regresi linear

$\mathrm{b}=$ koefisien regresi

Hasil sequensing amplifikasi DNA berupa urutan basa kemudian diedit secara manual menggunakan MEGA 6.0. Urutan basa yang sudah diedit kemudian dicocokan kemiripannya di Gene Bank pada halaman web NCBI dengan menggunakan BLAST serta membandingkan dengan referensi hasil sequensing lainnya.

\section{HASIL DAN PEMBAHASAN} Morfologi dan Morfometrik

Setelah diidentifikasi berdasarkan morfologinya dengan menggunakan buku identifikasi FAO Species Catalog Vol. 7 Clupeoid Fishes Of The World (Whitehead, 1985), 30 spesimen ikan yang diambil dari
Pasar Ikan Muara Angke diperkirakan masuk ke dalam famili Dussumieriidae, Ordo Clupeidae, yaitu golongan ikan sardin. Genus dari famili ini yang terdapat di Indonesia yaitu Dussumieria dan Spratelloides. Berdasarkan bentuk dan ukuran tubuh serta ornamen di tubuhnya, ikan ini masuk ke dalam genus Dussumieria, terlihat bahwa ikan memiliki tubuh yang ramping dan memanjang seperti cerutu dengan panjang berkisar hingga $14 \mathrm{~cm}$ dengan maksimal panjang dapat mencapai 20 $\mathrm{cm}$ (Whitehead, 1985), dengan perut yang membulat, tidak memiliki pre dan post pelvic scute, sedangkan pelvic scute berbentuk huruf "W", scute terletak diantara sirip perut dan dubur. Sirip perut dan punggung lebih mendekati ekor dibandingkan dengan kepala, kemudian sirip bagian perut kurang maju dari bagian tengah tubuhnya.

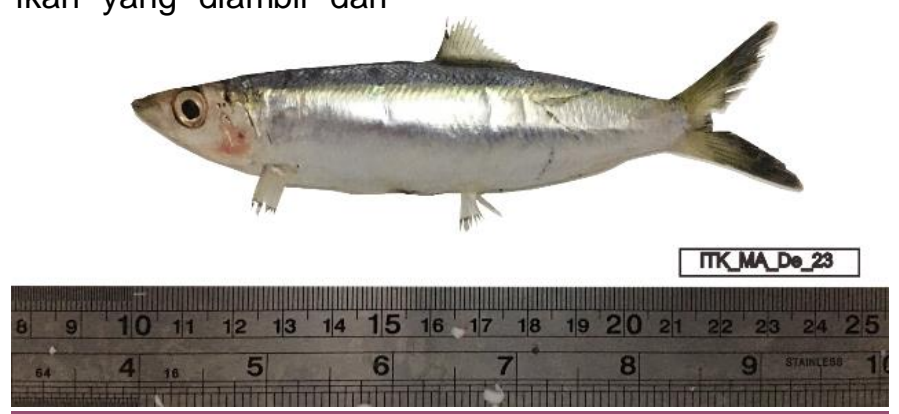

Gambar 2. Dussumieria elopoides (Dokumentasi pribadi, 2019)

Ciri lainnya yaitu memiliki tubuh yang berwarna silver atau keperakan dengan warna punggung hijau kebiruan,sehingga memberikan pantulan warna tubuh yang menyerupai pelangi, sebab itu ikan ini dikenal sebagai ikan sardin pelangi. Beberapa nelayan memberikan nama lokal pada ikan ini seperti Tembang Jawa, Tamban Buluh, Tamban Bulat, Tamban Bines, Tembang Bines dan Janggul. Ikan ini tidak memiliki duri punggung, namun memiliki sirip lunak punggung sejumlah 16 hingga 18 buah, kemudian terdapat sirip lunak anal sebanyak 14 hingga 18 buah, tidak ada striae pada bagian sisik posterior. Ikan ini merupakan ikan pelagis yang berkoloni atau schooling dan banyak tersebar di daerah Indopasific terkhusus di Perairan Indonesia (Sumatera, Utara Jawa dan Kalimantan). Makanan utamanya adalah plankton (Bukit et al., 2017). Genus Dussumieria sendiri memiliki 2 spesies yang sedikit sulit untuk dibedakan yaitu $D$. acuta dimana bentuk tubuh spesies ini lebih lebar dan pendek dibandingkan dengan $D$. elopsoides yang terlihat lebih silindris. Berdasarkan penjelasan morfologi tersebut dapat ditentukan bahwa ikan yang dimaksud merupakan jenis D. elopsoides (Bleeker,
1849). Hal tersebut juga dikuatkan dengan pengecekan molekuler menggunakan DNA barcoding pada Cytochrome C Oxydase Subunit I (COI).

Pengukuran morfometrik dapat membantu dalam identifikasi suatu spesies dan dapat melihat pula pola pertumbuannya. Hasil pengukuran morfometrik yang telah dilakukan berdasarkan Myers (2013) (Tabel 1).

Menurut Nair (1982) D. elopsoides sendiri memiliki lebar tubuh yang jauh lebih kecil dari panjang kepala, hal tersebut sesuai dengan data pengukuran morfometrik yaitu dengan lebar tubuh $1,8 \mathrm{~cm}$ dan panjang kepala $3 \mathrm{~cm}$. Nair (1982) juga menyebutkan bahwa panjang sirip ekor selalu kurang dari panjang kepala, dan hampir tiga kali lipat diameter matanya. $\mathrm{Hal}$ tersebut sesuai dengan data pengukuran morfometrik yaitu panjang sirip ekor (2,7-2,8 $\mathrm{cm})$, panjang kepala $(3 \mathrm{~cm})$, dan diameter matanya $(0,8 \mathrm{~cm})$.

Terjadi penurunan nilai panjang total badan ikan D. elopsoides. Menurut Whitehead (1985) panjang standar tubuh spesies ini yaitu bekisar 
Rahim dan Maduppa, Identifikasi Ikan Sardin Komersial (Dussumieria elopsoides)

$20 \mathrm{~cm}$, sedangkan rerata yang didapat dari hasil pengukuran yaitu 12,3 $\pm 1,1$ (Tabel 1 ). Whitehead (1985) juga mengatakan bahwa lebar badan berkisar 16 hingga $22 \%$ dari panjang total tubuh namun yang ditemukan hanya memiliki presentase $10 \%$ dari panjang total tubuhnya. Dari hasil tersebut dapat dikatakan bahwa terdapat penurunan bobot ikan $D$. elopsoides yang ditangkap pada saat ini. Hal ini dapat dikarenakan oleh gangguan lingkungan, ketersediaan makanan, maupun akibat dari tekanan aktivitas perikanan (Pauly, 2010). Berdasarkan perhitungan hubungan panjang berat, nilai koefisien $b$ yang didapat yaitu 2,7234 . Jadi, pola pertumbuhannya yaitu Alometrik Negatif yang ditunjukan dengan nilai b kurang dari $3 \quad(b<3)$. Adapun untuk $b<3$ menunjukkan bahwa pertambahan berat tidak secepat pertambahan panjang, $b=3$ artinya pertambahan panjang dan berat seimbang, dan untuk nilai $b>3$ pertambahan panjang lebih lambat dari pertambahan bobot.

Tabel 1. Hasil Pengukuran Morfometrik

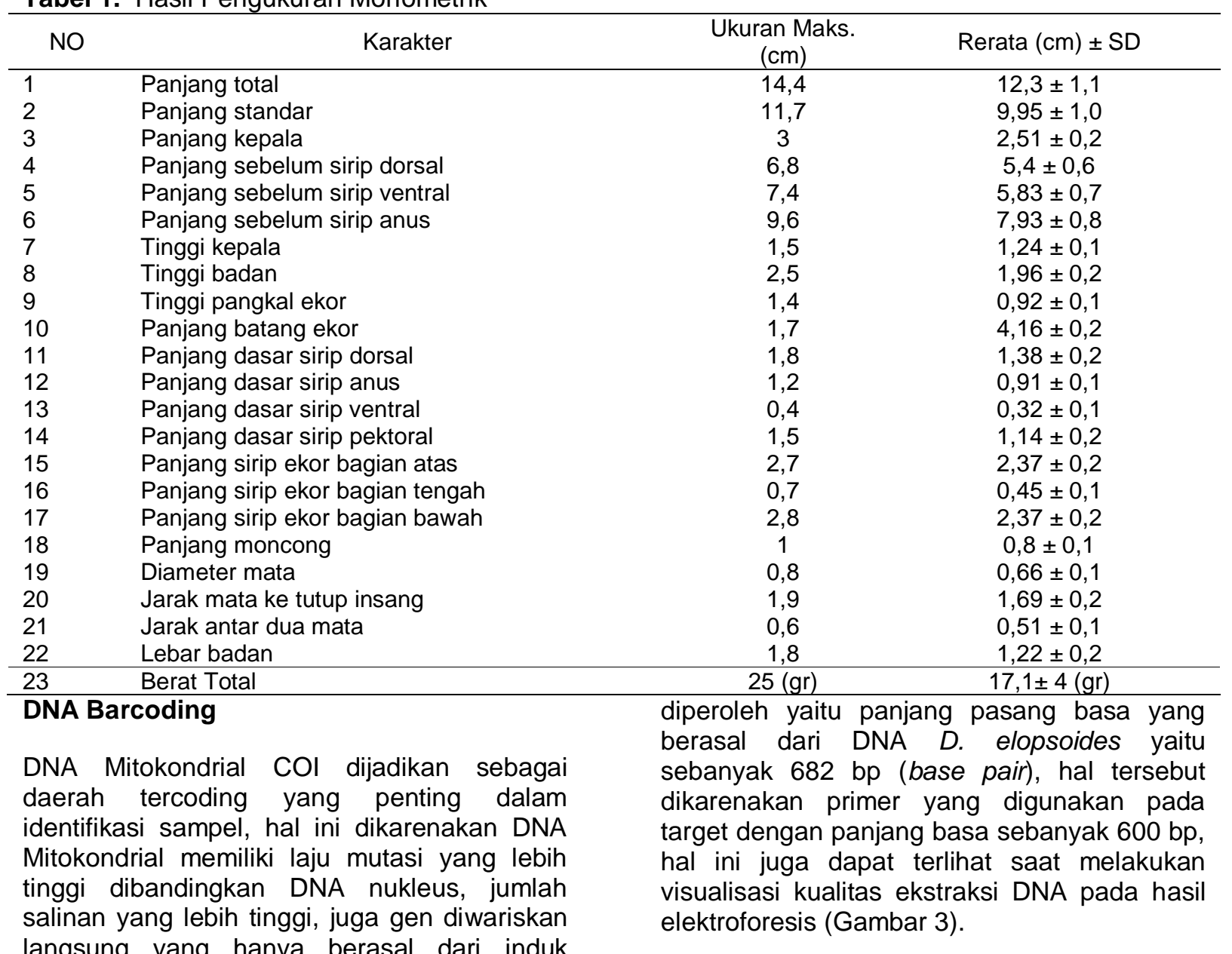
langsung yang hanya berasal dari induk (Amorim et al., 2019). Hasil analisis yang

\begin{tabular}{|l|}
\hline CCCTTTAAGTATTTGGTGCTTGAGCAGGGATAATTGGAACAGCCCTAAGCCTTTTA \\
ATTCGGGCAGAGCTAAGCCAACCAGGAGCACTCCTAGGAGATGATCAAATCTATA \\
ATGTCATCGTCACTGCGCACGCTTTTGTATAATTTCTTCATAGTAATCCTATCC \\
TGATCGGTGGCTTTGGAAACTGGCTTGTGCCTCTTATAATCGGGGCCCCAGATAT \\
GGCATTCCCACGAATGAACAACATGAGCTTCTGACTTCTACCTCCCTCCTTTCTCC \\
TTTTATTAGCTTCTTCTGGAGTTGAAGCTGGGGCAGGAACTGGCTGAACAGTATAC \\
CCCCCTTTAGCAGGAATCTAGCACATGCTGGTGCCTCAGTCGATCTAGCCATTTT \\
CTCCCTCCACTTGGCAGGTATTCCTCCATTCTAGGGCTATTAATTCATTACTAC \\
AATTATTAACATGAAACCCCCCGCAATTTCACAATATCAAACACCGCTGTTCGTCT \\
GAGCCGTACTTGTAACAGCCGTGCTTCTTCTCCTATCCCTACCCGTACTAGCCGCT \\
GGAATTACCATGCTACTCACAGATCGTAACTTAAATACCACTTCTTTGACCCAGC \\
AGGGGGAGAGACCCCATCCTTTACCAGCACTTATTCTGATTCTTTGGCCACCAG \\
AAAGTCTAAAA \\
\hline
\end{tabular}

Gambar 3. Penjejaran hasil sequen gen COI jenis Dussumieria elopsoides yang dikoleksi dari Pasar Ikan Muara Angke, Jakarta. 
Komposisi basa nukleotida dalam satu utas DNA lebih banyak mengandung pirimidin dibandingkan purin. 682 pasang basa yang dimaksud memiliki komposisi nukleotida Timin sebanyak $202(29,62 \%)$, Citosin 184 (26,98\%), Adenin 168 (24,63\%), dan Guanin 128 (18,77). Basa nukleotida yang mendominasi yaitu Timin yang mencapai $29,62 \%$. menunjukkan hasil kemiripan paling tinggi sebesar $91.64 \%$ dengan spesies Dussumieria elopsoides. Data teratas dari proses Basic Local Alignment Search Tool (BLAST) menggunakan Mitochondrial Cytochrome C Oxidase Subunit I (COI) sebagai target. Hasil Basic Local Alignment Search Tool (BLAST) (Tabel 2)

Hasil sequensing yang telah dicocokkan
kemiripannya pada GenBank NCBI

Tabel 2. Hasil BLAST Basa Nukleotida pada GenBank

\begin{tabular}{|c|c|c|c|c|c|c|}
\hline Description & $\begin{array}{l}\text { Max } \\
\text { Score }\end{array}$ & $\begin{array}{l}\text { Total } \\
\text { Score }\end{array}$ & $\begin{array}{l}\text { Query } \\
\text { Cover }\end{array}$ & $\begin{array}{l}E \\
\text { value }\end{array}$ & $\begin{array}{l}\text { Per. } \\
\text { Ident }\end{array}$ & Accession \\
\hline $\begin{array}{l}\text { Dussumieria elopsoides voucher } \\
\text { NBFGR:Dsht-B cytochrome oxidase subunit } \\
\text { I (COI) gene, partial cds; mitochondrial }\end{array}$ & 894 & 894 & $94 \%$ & 0.0 & $91.64 \%$ & FJ347960.1 \\
\hline $\begin{array}{l}\text { Dussumieria elopsoides voucher TR651EK } \\
\text { cytochrome oxidase subunit } 1 \text { (COI) gene, } \\
\text { partial cds; mitochondrial }\end{array}$ & 889 & 889 & $94 \%$ & 0.0 & $91.49 \%$ & KC500614.1 \\
\hline $\begin{array}{l}\text { Dussumieria elopsoides voucher } \\
\text { NBFGR:Dsht-A cytochrome oxidase subunit } \\
\text { I (COI) gene, partial cds; mitochondrial }\end{array}$ & 883 & 883 & $94 \%$ & 0.0 & $91,33 \%$ & FJ347959.1 \\
\hline $\begin{array}{l}\text { Dussumieria elopsoides voucher TR650EK } \\
\text { cytochrome oxidase subunit } 1 \text { (COI) gene, } \\
\text { partial cds; mitochondrial }\end{array}$ & 878 & 878 & $94 \%$ & 0.0 & $91,18 \%$ & KC500613.1 \\
\hline
\end{tabular}

Hasil sequensing yang telah didapat, kemudian dibandingkan dengan database GenBank NCBI (National Center for Biotechnologi Information) dan didapatkan kemiripan tertinggi dengan spesies $D$. elopsoides dengan Max Score dan Total Score 894, Query Cover 94\%, E-value 0.0, dan nilai Per. Ident sebesar $91.64 \%$. Menurut Triandiza dan Madduppa (2018), kemiripan tertinggi pada Genbank, dapat dicirikan dengan nilai max score dan total score yang sama, nilai Evalue yang bernilai 0 , serta nilai query cover dan nilai Per. Ident yang mendekati 100. Walaupun nilai Per.Ident sebesar 91.64\% nanum ia tetap dikatagorikan memiliki kemiripan yang cukup tinggi. Nilai E-value 0 juga menunjukkan hasil perbandingan dengan spesies lainnya bersifat identik dan nilai kepercayaan yang tinggi.

\section{KESIMPULAN DAN SARAN}

Hasil penelitian menunjukan bahwa pengamatan morfologi, pengukuran morfometrik, maupun verifikasi menggunakan DNA Barcoding pada spesimen ikan sardin yang dikoleksi dari Pasar Ikan Muara Angke, Jakarta merupakan jenis ikan Dussumieria elopsoides dengan presentase Query Cover sebesar 94\% dan Per. Ident sebesar 91,64\%. Terdapat penurunan massa dan panjang badan yang siginifikan dari sampel dibandingkan dengan literatur yang diacu. Hubungan antara panjang dan berat badan bersifat Alometrik negatif dimana pertambahan berat tidak secepat pertambahan panjang. Kedepannya penulis menyarankan studi lanjut berdasarkan genetika populasi Dussumieria elopsoides di beberapa wilayah di Indonesia.

\section{UCAPAN TERIMA KASIH}

Penulis mengucapkan banyak terima kasih kepada rekan-rekan Pascasarjana IImu Kelautan Institut Pertanian Bogor angkatan 2019, dan Asisten Mata Kuliah Biodiversitas Laut yang telah membantu dalam penelitian dan penulisan artikel ini.

\section{DAFTAR PUSTAKA}

Akbar, N. N., \& Labenua, R. (2018). Keragaman genetik Ikan Cakalang (Katsuwonus pelamis) di Perairan Laut Maluku Utara. DEPIK Jurnal IImu-IImu Perairan, Pesisir dan Perikanan, 7(2), 164-176.

Abdullah, A., \& Rehbein, H. (2016). DNA Barcoding for The Species Identification of Commercially Important Fishery Products in Indonesian Markets. International Journal of Food Science and Technology. 
Rahim dan Maduppa, Identifikasi Ikan Sardin Komersial (Dussumieria elopsoides)

Amorim, A., Fernandes, T., \& Taveira, N. (2019). Mitochondrial DNA in human identification: a review. PeerJ, 7, e7314.

Bukit, S. T. A. K., Affandi, R., Simanjuntak, C. P., Rahardjo, M. F., Zahid, A., Asriansyah, A., \& Aditriawan, R. M. (2017). Makanan ikan famili Clupeidae di Teluk Pabean, Indramayu. In: Hadie $W$, Hadiaty RK, Lusiastuti AM, Syafei LS, Hadie LE, Simanjuntak $C P H$, Haryono, Rahardjo MF, Affandi $R$ (Editors). Dalam: Prosiding Simposium Nasional Ikan dan Perikanan. Masyarakat Iktiologi Indonesia, Bogor, 12-13.

Hebert, P. D., Cywinska, A., Ball, S. L., \& Dewaard, J. R. (2003). Biological identifications through DNA barcodes. Proceedings of the Royal Society of London. Series B: Biological Sciences, 270(1512), 313-321.

Jefri, E., Zamani, N. P., Subhan, B., \& Madduppa, H. H. (2015). Molecular phylogeny inferred from mitochondrial DNA of the grouper Epinephelus spp. in Indonesia collected from local fish market. Biodiversitas Journal of Biological Diversity, 16(2)., 254-263.

Keskin, E., \& Atar, H. H. (2013). DNA barcoding commercially important fish species of T urkey. Molecular ecology resources, 13(5), 788-797.

Ko, H. L., Wang, Y. T., Chiu, T. S., Lee, M. A., Leu, M. Y., Chang, K. Z., ... \& Shao, K. T. (2013). Evaluating the accuracy of morphological identification of larval fishes by applying DNA barcoding. PLoS One, 8(1), e53451.

Kripa, V., Mohamed, K. S., Koya, K. P., Jeyabaskaran, R., Prema, D., Padua, S., ... \& Dhanya, A. M. (2018). Overfishing and climate drives changes in biology and recruitment of the indian oil sardine sardinella longiceps in Southeastern Arabian Sea. Frontiers in Marine Science, 5, 443, 1-20

Maulid, D. Y., Nurilmala, M., Nurjanah, N., \& Maddupa, H. (2016). Molecular Characteristics of Cytochrome $\mathrm{B}$ for Mackerel Barcoding. Jurnal Pengolahan Hasil Perikanan Indonesia, 19(1), 9-16.

Myers, P., R. Espinosa et al., (2013). http:// animal diversity. ummz. umich. Edu /collections/contributors/Grzimek_fish/Cl upeiformes/Chirocentrus_dorab/. [accessed date : 06 Desember 2019

Nair, P. N. (1982). On the systematics of rainbow sardines Dussumieria spp.(Family: Dussumieriidae, Pisces) from Indian waters. Journal of the Marine Biological Association of India, 24(1\&2), 80-91.

Nurilmala, M., Widyastuti, U., Kusuma, W. A., Nurjanaha, N., Wulansari, N., \& Widyatuti, Y. (2016). DNA barcoding for identification of processed tuna fish in Indonesian market. Jurnal Teknologi, 78(4-2), 115-118.

Pauly, D. (2010). Gasping fish and panting squids: oxygen, temperature and the growth of water-breathing animals. In: Excellence in Ecology. Book 22. O. Kinne (Ed.). International Ecology Institute, Oldendorf/Luhe, $216 \mathrm{p}$

Santos, M. N., Gaspar, M. B., Vasconcelos, P., \& Monteiro, C. C. (2002). Weight-length relationships for 50 selected fish species of the Algarve coast (southern Portugal). Fisheries research, 59(1-2), 289-295.

Sekretaris Jenderal Kementerian Kelautan Perikanan Republik Indonesia. (2018). Buku Laporan Tahunan 2017 Kementerian Kelautan dan Perikanan Republik Indonesia.

Sembiring, A., Pertiwi, N. P. D., Mahardini, A., Wulandari, R., Kurniasih, E. M., Kuncoro, A. W., ... \& Carpenter, K. E. (2015). DNA barcoding reveals targeted fisheries for endangered sharks in Indonesia. Fisheries Research, 164, 130-134.

Strauss, R. E., \& Bond, C. E. (1990). Taxonomic methods: Morphology in Methods for Fish Biology: C. B. Shreck \& P. B Moyle (Eds). Am. Fish. Soc. Bethesda, Maryland. USA.

Triandiza, T., \& Madduppa, H. (2018). Aplikasi Analisa Morfologi dan DNA Barcoding Pada Penentuan Jenis Kepiting Porcelain (Pisidia sp.) Yang Berasal dari Pulau Tunda, Banten. Jurnal Sumberdaya Akuatik Indopasifik, 2(2).

Ward, R. D., Zemlak, T. S., Innes, B. H., Last, P. R., \& Hebert, P. D. (2005). DNA barcoding Australia's fish species. Philosophical Transactions of the Royal Society B: Biological Sciences, 360(1462), 1847-1857.

Whitehead, P. J. P. (1985). FAO species catalogue, Vol. 7. Clupeoid fishes of the world. An annotated and illustrated catalogue of the herrings, sardines, pilchards, sprats, anchovies and wolf herrings. Part 1-Chirocentridae, Clupeidae and Pristigasteridae. FAO Fish. Synop., 125, 303. 